\title{
Homo Oeconomicus and Behavioral Economics
}

\author{
Justyna Brzezicka', Radosław Wisniewski
}

ABSTRACT

Recent years have witnessed a growing interest in behavioral trends in both economic theory and practical applications. As a science with vast potential for explaining complex market behaviors, behavioral economics is drifting away from the classical model of homo oeconomicus deployed by mainstream economics.

This paper discusses the significance and role of the homo oeconomicus model in light of behavioral economics. It analyzes the direction of changes affecting homo oeconomicus, examines the definition of anomalies within the context of behavioral economics and discusses the anomalous status of homo oeconomicus. The paper proposes a hypothesis that the attitude characterizing homo oeconomicus is unique and incidental. The presented interdisciplinary analysis relies on economics, behavioral economics, economic psychology, behavioral finance and the methodology of science to discuss the homo oeconomicus model. The paper reviews change trends in economics, which are largely propelled by advancements in behavioral economics.

The key methodological tools deployed in this paper are theoretical analysis and a compilation of extensive research findings. The results were used to formulate new theories advocating the development of a modern approach to the homo oeconomicus model, recognizing its significance and the growing importance of behavioral economics.

KEY WORDS: $\quad$ behavioral economics; homo oeconomicus; economic man; real man

JEL Classification: $\quad$ D03; A12; B00

${ }^{1}$ University of Warmia and Mazury in Olsztyn - Department of Real Estate Management and Regional Development, Poland

\section{Initial remarks}

Economic anomalies and the homo oeconomicus model receive broad coverage in the literature of economics. The aims of the present paper are to: 1) analyze anomalies within the context of behavioral economics, 2) postulate the need to redefine the concept of homo oeconomicus or replace the term economic man with

Correspondence concerning this article should be addressed to: Wisniewski, Radoslaw University of Warmia and Mazury in Olsztyn - Department of Real Estate Management and Regional Development Prawocheńskiego 15 Str., Olsztyn, Warmińsko-Mazurskie 10-720 Poland. T: +48 8952349 75. E-mail: danrad@uwm.edu.pl real man, and 3) examine whether homo oeconomicus can be classified as an anomaly in economics. New economic trends give rise to analyses and debates concerning problematic areas. The investigated viewpoints are by no means regarded as established truths but are rather examined with a critical eye.

This paper was inspired by the bold and scientifically intriguing hypothesis proposed by Leibenstein (1976), who suggests that homo oeconomicus is not a model case but an extreme form of behavior that surfaces under extraordinary circumstances ${ }^{1}$. This paper hypothesizes that homo oeconomicus is a manifestation of a very special form of behavior. 
The presented deliberations are of a theoretical nature, which is not to say they lack practical significance. The content of the paper has been organized to correspond with the aims and with topics expanded on in relation to the behavioral approach. A few remarks that will allow us to establish a scientific basis should be made from the outset. Two issues are important as far as the aims of the paper are concerned: the first is the dynamic development of economics, extending well beyond its former scope of interest; the second is the growing potential of the behavioral approach in economics. In an attempt to characterize contemporary economics, Wojtyna (2008, pp. 9-10) argues that the harsh criticism of economics does not stem from its stagnation. Rather, economics is a dynamic and rapidly developing field of science that effectively colonizes other areas of life. Lazear (2000) relies on a more figurative comparison to address imperialistic trends in economics. He defines economic imperialism as an extension of economics to include topics that go beyond the classical scope of issues. Ludwig von Bertalanffy's systems approach is an early example of a theory that anticipated the expansion of economics to other areas of life. Issues concerning the explanatory potential of behavioral economics, due to a psychological approach, are raised by (Camerer \& Loewenstein, 2004, p. 3), whereas (Camerer, Loewenstein, Precel, 2005, p. 1) touch not only on implementing elements of psychology in economics but also extending them to other regions of knowledge. "In the last two decades, following almost a century of separation, economics has begun to import insights from psychology. "Behavioral economics" is now a prominent fixture on the intellectual landscape and has spawned applications to topics in economics, such as finance, game theory, labor economics, public finance, law, and macroeconomics" (Camerer et al., 2005, p. 1).

This means that postulates arguing that economics remains in lethargy are clearly undermined by the achievements noted over the past fifty years. The new field of academic inquiry, behavioral economics, put an end to the inertia in economic thought. Behavioral economics combines various fields of study, often unrelated, that are unified by a common goal, namely, an attempt to explain anomalies in mainstream economics.

\section{Behavioral economics - the potential of the discipline}

As a worthy representative of the social sciences, behavioral economics has achieved what its mother, economics, had been unable to accomplish. It sheds light on human nature and restores psychology, a field hitherto unaccounted for in economic analysis, to grace (Schwartz, 2008, p. 8). In addition to being the focal point of behavioral economics, psychology is also an area of particular interest in this paper.

What underlies the success behavioral economics has enjoyed? As an experimental science, behavioral economics combines economic deduction with psychological induction (Hilton, 2008, p. 21), economic logic of choice with psychological analysis of human behavior (Maital \& Maital, 1993, p. 3), and formal and normative models of economic behavior determined by principles of rationality with a psychological approach to financial decisions made by humans (Zaleśkiewicz, 2011, p. 20). Economics and psychology play complementary roles in sciences that human choices (Hogarth \& Reder, 1987, p. 1). The achievements of behavioral economics largely result from applying the scientific approach: behavioral economics is an experimental science (Camerer \& Loewenstein, 2004 , p. 8) that uses the scientific approach to test and better understand economic theories. As noted by Crawford (1997, p. 207), experimental data are frequently the most important source of information and are no less reliable than casual empiricism or introspection. According to Guala (2003, p. 5), the experimental approach to economics allows for genuine scientific knowledge to be introduced into the philosophy of science. Bardsley et al. (2010) notes that the rise of experimental economics should provoke a degree of methodological controversy.

The experimental turns in economics mark a clear departure from the earlier gained methodological wisdom and have happened very fast. When put in such a way, the term experimental economics can naturally be used to encompass all experimental studies (see Bardlsley, 2010, p. 2). Behavioral economics is largely based on experiment, e.g., the studies conducted by Tversky and Kahneman (Kahneman \& Tversky, 1979; 1984; Tversky \& Kahneman, 1981) are no different from a laboratory experiment investigating individual decision-making with a particular focus on decisions 

money. The results of studies conducted by Sanfey et al. (2003) using magnetic resonance imaging show that in cases where the game results in the rejection of the offer by the second player, areas of the brain responsible for emotion and perception are stimulated, with the increase in the first indicating the significant role of emotions in the decision-making process. Follow up studies by Sanfey (2007) also highlight the significance of the social context in this process.

The significance of the achievements of behavioral economics can also be observed where the theory of games is concerned, which aims to assess optimal behavior in the case of a conflict of interest. The theory of games enables social interactions to be described and the differences between theoretical models and experimental data to be recognized using mathematical tools. "The dialog between theory and observations created an approach called "behavioral game theory," which is a formal modification of rational game theory, aided by experimental evidence and psychological intuition. The modifier "behavioral" is a reminder that the theory is explicitly intended to predict behavior of people (and collectivities such as firms), and draws as directly as possible on evidence from psychology to do so" (Camerer, 2003, p. 465). Ho, Camerer \& Chong (2007) use a one-parameter theory of learning in games, namely, self-tuning experience weighted attraction (EWA). In their work, the self-tuning EWA model can turn from a weighted fictitious game into an averaging reinforcement, learning as subjects equilibrate and learn to ignore inferior foregone payoffs. The theory was tested on seven different games. The functions in the self-tuning EWA seem to be robust across games. The basic conclusions are replicated in those games that have incomplete information, with choices made by groups rather than individuals.

The aforementioned social context should not be ignored when dealing with the topic at hand. Behavioral economists have taken Aristotle's observations one step further: man is by nature a social animal, and human relationships are not always consciously formed but deeply affect an individual's thoughts and actions (Etzioni, 2011a, p. 282). The Behavioral economist manifesto was formulated nearly a century ago, but certain patterns have been reincarnated and transferred to the realm of behavioral economics. Although BE does not make a literal reference to Watso- nian behaviorism (Watson, 1913), the observation that humans, similarly to animals, are dependent on their environment and circumstances, indicates a powerful relationship between Darwinism and cognitive psychology (Lea, 2008, p. 513), whereas the connections they form within a system, where societies, work and friendship function, are of a permanent nature (Baumeister, 2005).

Elements that are dependent on human nature are an indispensable part of economic life. Although they are absent from many classical models, their significance is growing rapidly, as demonstrated by recent and numerous publications in the field. The above comparison can be used to reformulate our main hypothesis: does the homo oeconomicus represent an anomalous attitude in light of the achievements in economic theory?

\section{Anomaly in behavioral economics}

The main aim of research in behavioral economics is to explain hitherto unexplored issues that have been regarded as anomalies. This term is frequently used in the behavioral economics literature to expose irregularities in mainstream economics. The areas marginalized by conventional economic theory are the focal point of behavioral economics. "Rarely has a field in economics been so strongly dominated by one set of authors as has been the case with anomalies" (Frey \& Stutzer, 2007, p. 3).

The above observations are exemplified in this chapter. The problem of anomalies has been systematized due to overlapping fields of research that investigate: 1) the nature of anomalies, 2) areas where anomalies occur, and 3) the role and significance of anomalies.

An anomaly is a contradiction between standard decision theory and reports of subjects' behavior (Smith, 2005 , p. 144). The shift in emphasis to behavior made the concept of anomaly the focal point of behavioral economics, which, in the simplest of terms, addresses the behavior of subjects.

In accordance with the viewpoint presented by Smith (2005, p. 144), an anomaly is the difference between behavior described by a model or theory and actual observed behavior. When put in such a way, an anomaly is understood as a deviation of an element of a model or theory from the actual model or theory, noticeable under the influence of the subject's 

The cited examples illustrate that aberrant results in neoclassical economic theory are regarded a priori as anomalies in the literature. Behavioral economics agglomerates anomalies into a coherent whole and makes them the focal point of its research. Economic anomalies and paradoxes discovered by psychology have been grouped along two axes. The first axis focuses on cognitive limitations that cause anomalies. The second axis comprises efforts to fit anomalies with economic theories and transform them into "regular" events. There is also a third, frequently neglected approach that proposes analyzing stimuli and the subjects' responses to anomalies (Frey \& Stutzer, 2007, p. 4).

The discussion presented in this chapter fulfills the first aim of this paper, which is to analyze anomalies within the context of behavioral economics.

\section{Homo oeconomicus in behavioral economics - change trends}

The belief that homo oeconomicus is an authentic attitude is an immanent characteristic of classical economics, but a discussion about homo oeconomicus would not be complete without a reference to this conceptualization that stems from behavioral economics.

Behavioral economists formulate explicit reservations to the homo oeconomicus and question the validity of the classical model in economic analyses. The shortcomings of the original homo oeconomicus model result mainly from: 1) the implied absence of complete information in the decision process, 2) the omission of learning, 3) marginalizing the inherent attributes of human nature, and 4) the assumption that subjects are fully rational. Behavioral economics introduced to economics research a positive rather than normative psychological model that deals with what is as opposed to what should be (Katona, 1975, p. 41).

The maximization of economic profit and the possession of complete knowledge about the environment should be verified to account for routine and opportunistic actions that result from limitations in the operating environment. The classical homo oeconomicus is like a cyborg calculating costs and profits: he lacks passion, does not give in to temptations, and is not greedy nor altruistic. The literature, on the other hand, provides us with a series of reports regarding integrity in regard to behavioral economics (Bolton \& Ockenfels, 2000; Fehr \& Schmidt, 1999; Kahneman, Knetsch
\& Thaler, 1986; Rabin, 1993), confirming the complexity of people's motives and altruistic inclinations. The studies of Rabin (1993) contradict the assumption that people work only in their own interest, not caring about "social goals". The paper presented a model that accounts for the "element of integrity", that is, the readiness of people to sacrifice their own materialistic well-being to help someone who is kind or punish one who is not, although the model does suggest that behavioral implications are greatest when the material consequences are not too significant. General results that can be applied to specific economic situations were also indicated in the work. The studies of Fehr \& Schmidt (1999, p. 818) confirm that there is a fraction of people who are also motivated by fairness considerations and that the classical theory of the homo oeconomicus with purely egotistical motives is not observed in real life. Thaler discusses the preferred changes in the process of adapting homo oeconomicus to reality. A reduction in the model of information processing capacity, the introduction of emotions and, consequently, a better understanding of human cognitive ability (Thaler, 2000) are required to adjust homo oeconomicus to its operating environment. The neoclassical homo oeconomicus model, which ignores the above elements, is clearly "antibehavioral" (Mullainathan \& Thaler, 2001, p. 1094).

Second, traditional economic models disregard the learning process and assume that the subject solves a given problem at the first attempt. When the learning category is introduced into the model, homo oeconomicus learns rapidly; he draws conclusions from a single mistake and finds ways to avoid future errors (Thaler, 2000).

Third, the homo oeconomicus theory oversimplifies human nature and undermines the validity of claims that are based on it, whereas behavioral economics emphasizes the attributes and shortcomings of human nature that are vital for economics (Katona, 1980, p. 3). The work of Damasio (2008) indicates that emotions are indispensable for daily activities. The brain is responsible for coordinating emotions and decisions, and dysfunctions in this area of the brain lead to decisions that are ineffective and irrational. This fact is also confirmed by studies in the field of neuroeconomics mentioned earlier (see Sanfey et al., 2003; Sanfey, 2007). According to Thaler (2000, p. 120), homo oeco- 

of imperfect knowledge economics, which is based on the truism that market participants have imperfect knowledge, to criticize behavioral economist and classical theoreticians. The reason behind such strong criticism of both stances can be found in the lack of internal congruity in the two approaches due to the presence of a deterministic element. No one, including economists, is able to fully describe a change before it takes place (Frydman \& Goldberg, 2007).

In conclusion, a few words should be said about two approaches to "saving" the homo oeconomicus concept. The first involves a change in fundamental principles that underlie the homo oeconomicus model. The significance of the psychological background of economic decisions has been recognized, and greater emphasis has been placed on limited rationality, incomplete knowledge, and the accumulation of knowledge. These components can be used to redefine the homo oeconomicus model. The second approach proposes to replace homo oeconomicus with the concept of a real man who possesses the above qualities. The above observation contributes to the fulfillment of the second aim of this paper, which postulates the need to redefine the concept of homo oeconomicus or to replace the term economic man with real man.

\section{Future prospects}

An overview of trends in economic thought supports a prediction of the type and direction of changes that will take place in economic theory. At present, alternative economics is more of a critique of the weaknesses in mainstream economics than a partner offering an alternative set of tools for economic inquiry. In the future, however, the significance of behavioral economics will continue to grow as a field that analyzes the real motives and attributes of human behavior in a complex and uncertain environment of contemporary economic systems. The described changes are already taking place, and we are all witnessing the behavioral transformation, which is also a cultural transformation (Rubinstein, 2006 , p. 1). The rapid emergence of numerous publications has changed behavioral economics from a niche topic to one that is well represented in the major journals (Fudenberg, 2006, p. 694). A new area of inquiry, behavioral economics engineering, has emerged in response to the failure of economics to address the challenges of the real world (Bolton \& Ockenfels, 2012).
Zawiślak (2011, pp. 363-364) argues that "the limited reliability of economic postulates stems from the fact that the perceived world undergoes continuous change (...). A pragmatist would point to the crisis of a paradigm in a theory which aspires to gain practical value." This is a serious problem: if social and economic decisions are made based on inadequate theories, actions will bring unexpected consequences instead of the anticipated goals. Zawiślak also postulates the hypothesis that "economics finds it very difficult to present timeless, universal truths," and he backs his claim with two arguments: 1) reality is changeable and automatically invalidates all generalizations, and 2) human behavior is changeable when the principles discovered by theoreticians are deployed by the authorities.

Various authors have postulated the need to formulate a new paradigm based on the possibilities offered by behavioral sciences (Etzioni, 2011b, p. 1099; Hogarth \& Reder, 1987, p. 4; Schwartz, p. 21; Sontheimer, 2006, p. 237; Wojtyna, 2008, p. 30; Zawiślak, 2011, p. 367; and others). Zawiślak (2011, p. 367) identifies four phases in the process of changing the paradigm in economic sciences: 1 ) departing from the concept of a human being as an absolutely rational homo oeconomicus, 2) accounting for ideas as value-forming factors, 3) accounting for exogenous variables outside an economic model that influence the price, and 4) focusing on the decision-maker's psychological background, which is the primary mechanism influencing his actions. This process aims to develop a new paradigm based on behavioral economics.

When referring back to the essence of a paradigm according to Kuhn (Kuhn 1970), the behavioral sciences fulfill the criteria through which an "achievement" can be considered a paradigm. According to Kuhn (1970, p. 10), we can talk about a paradigm when two traits occur simultaneously: the achievements represented by the new approach must be original and attractive enough to draw the attention of a constant group of adherents of a given theory away from competing means of carrying out scientific work. At the same time, however, these achievements must be open enough to have left the new school with a variety of problems to solve. This term is intended to indicate that certain accepted examples of scientific practice, such as covering rights, theories, applications and technical possibilities, together build a model from which a coherent tradition of scientific research emerges. On the other hand, the economic revolution, whose sig- 
nificance is emphasized by Grobler (2006), has already begun. In this context, the anomalies themselves, their occurrence, and their infringement on the former assumptions can become either a prediction and cause of scientific crises and revolutions to come or a prognosis of changing paradigms (Kuhn 1970, p. ix)

The literature is full of reports that contradict the abovepresented optimistic pro-behavioral approach. Fudenberg (2006) lists numerous objections regarding the form and methodology of behavioral economics studies. One example is the difficulty of presenting certain phenomena using formal models (e.g., framing and context). Another is the susceptibility of experimental data to manipulated results. For example, under the temptation of money prizes used in experiments, the answers may be dependent on the type of gratification and other factors, such as having it denied. Parts of many analyses also remain unexplained in behavioral studies, and the problem of results in strategic games in the form of equilibrium can arise as the result of a non-equilibrium process of learning, imitation, or adaptation. There is also a series of problems that stem from the experimental nature of behavioral economics. One of the main problems is "the problem of external validity or how to generalize experimental results to nonlaboratory settings," Guala (2003, p. 5).

When summarizing these discussions, it is worth mentioning the findings of Fudenberg (2006, p. 695) regarding the assessment of behavioral economics in terms of three criteria of economic theories formulated by George Stigler (1965): "I think that theories (both in economics and more generally) should be judged by George Stigler's (1965) three criteria: the accuracy of predictions, generality, and tractability. The standard model of individual behavior does very well in terms of generality and tractability, but behavioral economics has helped highlight some areas where the standard model's predictions are sufficiently wide of the mark that changes are valuable. The challenge for the field is to generate more accurate predictions without sacrificing too much on Stigler's two other criteria." Observations regarding the lower tractability of behavioral economic models have also been emphasized by Camerer \& Loewenstein (2004, p. 4).

\section{Conclusions}

It can be concluded that behavioral trends play an increasingly important role in contemporary economics. Behavioral economics offers more realistic explanations of human decisions and macroeconomic processes than the neoclassical approach. It is rapidly invading other areas of life such as psychology and is entering the economic realm. It has been emphasized that although theoreticians are divided over the permeation of psychology and sociology into economic theory, the social sciences will continue to place greater emphasis on factors that affect the decision process. The growing significance of research into individual decision-making leads to the very center of behavioral economics.

Homo oeconomicus has become a stronghold of neoclassical economics. Generations of economists, politicians, entrepreneurs and institutions have relied on the homo oeconomicus model without giving much thought to the gap between reality and theories that often fail. Homo oeconomicus is an archetype that is losing its validity. An effective model that would fit the uncertain environment of the contemporary economy, a role that was to be fulfilled by homo oeconomicus, has not yet been developed. We should explore the depths of human nature, test the boundaries of the existing models and focus on areas that have been omitted in order to lay the foundations for a new concept. The model should deliver an accurate representation of reality or risk being irrelevant. It should distribute the main accents in such a way as to support the optimal substitution of relative simplification and the functional representation of reality based on structural data.

The homo oeconomicus model should be adapted to the new reality by drawing upon our expanded knowledge of human nature, rationality and decision-making. The definition of the economic man has changed considerably throughout the centuries, as traditional society, where man was merely a factor of production, evolved into a modern society that witnessed the birth of the individual (Adamkiewicz-Drwiłło, 2008, p. 233). "Man is not rational, predictable, quantifiable, essentially good, resistant to irrational determination (...) he is a creator and the first subjective entity in history" (Sepkowski, 2005, p. 11). A universal homo oeconomicus does not exist because the criteria of rationality in a given social and economic system are closely correlated with the thinking patterns of the system's members. A shift in emphasis to man has revealed that psychology, the human mind and emotions significantly influence economic processes.

The role of the homo oeconomicus model (in its original meaning) is diminishing in contemporary economics. 
Neoclassical economics turned departures from convention into anomalies. It marginalized limited rationality, incomplete knowledge and the complexity of human nature. Behavioral economics focuses on weaknesses and has turned them into strengths. Attempts should be made to reverse viewpoints, and the same approach can be used to relate behavioral economics to neoclassical economics, where weaknesses are questioned and looked at as anomalies. The homo oeconomicus model seems to be the main weakness of neoclassical economics. From the neoclassical perspective, an individual endowed with the attributes of homo oeconomicus does not exist in reality; such an individual is an impossibility, an exception that proves the rule. The above discussion fulfills the third goal of this paper, which was to examine whether the homo oeconomicus attitude can be classified as an anomaly in economics. The main hypothesis can also be verified: homo oeconomicus may be classified as an anomaly - not in economics as a general science, but in behavioral economics as a sub-field of economics. An extrapolation of the anomalous status of homo oeconomicus to general economics would be yet another unwelcome simplification in its history. The revised goal is likely to be achieved in the future if behavioral economics continues to develop at the current rapid pace.

\section{References}

Adamkiewicz-Drwiłło, H. G. (2008). Wspótczesna metodologia nauk ekonomicznych [Current methodology of economic sciences]. Toruń: Dom Organizatora.

Akerlof, G. A., \& Shiller, R. J. (2009). Animal spirits: How human psychology drives the economy, and why it matters for global capitalism. Princeton, NJ: Princeton University Press.

Bardsley, N., Cubitt, R., Loomes, G., Moffatt, P., Starmer, C., \& Sugden, R. (2010). Experimental economics: Rethinking the rules. Princeton, NJ: Princeton University Press.

Baumeister, R. F. (2005). The cultural animal: Human nature, meaning, and social life. New York, NY: Oxford University Press.

Blaug, M. (1992). The methodology of economics: Or, how economists explain ( $2^{\text {nd }}$ ed.). Cambridge, UK: Cambridge University Press.

Bolton, G. E., \& Ockenfels, A. (2000). ERC: A theory of equity, reciprocity, and competition. American Economic Review, 90 (1), 166-193.
Bolton, G. E., \& Ockenfels, A. (2012). Behavioral economic engineering. Journal of Economic Psychology, 33 (3), 665-676.

Camerer, C. (2003). Behavioral game theory: Experiments in strategic interaction. Princeton, NJ: Princeton University Press.

Camerer, C. F., \& Loewenstein, G. (2004). Behavioral Economics: Past, Present, Future. In C. F. Camerer, G. Loewenstein, \& M. Rabin (Eds.), Advances in Behavioral Economics (pp. 3-51). Princeton, NJ: Princeton University Press.

Camerer, C., Loewenstein, G., \& Prelec, D. (2005). Neuroeconomics: How neuroscience can inform economics. Journal of Economic Literature, 43 (1), 9-64.

Crawford V.P. (1997). Theory and experiment in the analysis of strategic interactions. In D. Kreps and K. Wallis (Eds.), Advances in Economics and Econometrics: Theory and Applications (Vol. 1, pp. 206-242). Cambridge, UK.: Cambridge University Press.

Damasio, A. (2008). Descartes' error: Emotion, reason and the human brain. New York, NY: Random House.

DellaVigna, S. (2009). Psychology and Economics: Evidence from the Field. Journal of Economic Literature, 47 (2), 315-372.

Etzioni, A. (1988). Moral Dimension: Toward a New Economics. New York, NY: Free Press.

Etzioni, A. (2011a). Behavioural Economics: Next Steps. Journal of Consumer Policy, 34 (3), 277-287.

Etzioni, A. (2011b). Behavioral Economics: Toward a New Paradigm. American Behavioral Scientist, 55 (8), 1099-1119.

Fehr, E., \& Schmidt, K. M. (1999). A theory of fairness, competition, and cooperation. The Quarterly Journal of Economics, 114 (3), 817-868.

Fetchenhauer D., Azar O. H., Antonides G., Dunning D., Frank R. H., Lea S., \& Ölander F. (2012). Monozygotic twins or unrelated stepchildren? On the relationship between economic psychology and behavioral economics. Journal of Economic Psychology, 33 (3), 695-699.

Frey B. S., \& Stutzer A. (2007). Economics and Psychology: Developments and Issues. In B. Frey, \& A. Stutzer (Eds.), Economics and Psychology. A Promising New Cross-Disciplinary Field ( $p$ p. 3-15). Cambridge, MA: MIT Press.

Frydman, R., \& Goldberg, M. D. (2007). Imperfect knowledge economics: Exchange rates and risk. 
Princeton, NJ: Princeton University Press.

Fudenberg, D. (2006). Advancing beyond advances in behavioral economics. Journal of Economic Literature, 44 (3), 694-711.

Gowdy, J. M. (2008). Behavioral economics and climate change policy. Journal of Economic Behavior \& Organization, 68 (3-4), 632-644.

Grobler, A. (2006). Metodologia nauk [The Methodology of Science]. Kraków: Wydawnictwo Znak-Aureus.

Guala, F. (2005). The methodology of experimental economics. Cambridge, UK.: Cambridge University Press.

Hilton, D. (2008). Theory and method in Economics and Psychology. In A. Lewis (Ed.), The Cambridge Handbook of Psychology and Economic Behaviour (pp. 9-36). Cambridge, UK: Cambridge University Press.

Ho, T. H., Camerer, C. F., \& Chong, J. K. (2007). Selftuning experience weighted attraction learning in games. Journal of Economic Theory, 133 (1), 177-198.

Hogarth, R. M., \& Reder, M. W. (1987). Introduction: Perspectives from Economics and Psychology. In R. M. Hogarth \& M.W. Reder (Eds.), Rational Choice. The Contrast between Economics and Psychology (pp.1-23). Chicago, IL: University of Chicago Press.

Kahneman, D. (2003a). A psychological perspective on economics. American Economic Review, 93 (2), 162-168.

Kahneman, D. (2003b). Maps of bounded rationality: Psychology for behavioral economics. American Economic Review, 93 (5), 1149-1475.

Kahneman, D., Knetsch, J., Thaler, R. (1986). Fairness as a constraint on profit seeking: Entitlements in the market. American Economic Review, 76 (4), 728-741.

Kahneman D., \& Tversky A. (1979). Prospect theory: An analysis of Decision under risk. Econometrica, 47 (2), 263-292.

Kahneman D., \& Tversky A. (1973). On the psychology of prediction. Psychological Review, 80 (4), 237-251.

Kahneman, D., \& Tversky, A. (1974). Judgment Under Uncertainty: Heuristics and Biases. Science, 185 (4157), 1124-1131.

Kahneman, D., \& Tversky, A. (1984). Choices, values, and frames. American psychologist, 39 (4), 341-350.

Katona, G. (1975). Psychological Economics. New York, NY: Elsevier.

Katona, G. (1980). The Scope and Function of Behavioral Economics. In G. Katona (Ed.), Essays on
Behavioral Economics (pp.1-23). Ann Arbor, MI: The University of Social Research, The University of Michigan.

Koumakhov, R. (2009). Conventions in Herbert Simon's theory of bounded rationality. Journal of Economic Psychology, 30 (3), 293-306.

Kuhn, T. S. (1970). The structure of scientific revolutions (2nd ed.). Chicago, IL: University of Chicago Press.

Lazear, E. P. (2000). Economic imperialism. The Quarterly Journal of Economics, 115 (1), 99-146.

Lea, S. E. G. (2008). Evolutionary psychology and economic psychology. In A. Lewis (Ed.), The Cambridge Handbook of Psychology and Economic Behaviour (pp. 512-526). Cambridge, UK: Cambridge University Press.

Leibenstein, H. (1976). Beyond Economic Man. A new foundations for Microeconomic, London, UK: Harvard University Press.

Leibenstein, H. (1978). On the basic proposition of Xefficiency theory. The American Economic Review, 68 (2), 328-332.

Lohrenz, T., \& Montague, P. R. (2008). Neuroeconomics: what neuroscience can learn from economics. In A. Lewis (Ed.), The Cambridge Handbook of Psychology and Economic Behaviour (pp. 457-492). Cambridge, UK: Cambridge University Press.

Maital, S., \& Maital, S. L. (1993). Psychology and Economics. In S. Maital \& S.L. Maital (Eds.), Economics and Psychology (pp. 3-35). Aldershot, UK: Edward Elgar Publishing Limited.

Morawski, W. (2011). Socjologia ekonomiczna. Problemy. Teoria. Empiria [Economic sociology. Problems. Theory. Empiricism]. Warszawa: PWN.

Mullainathan, S., \& Thaler, R. H. (2001). Behavioral Economics. In International Encyclopedia of the Social \& Behavioral Sciences. (pp. 1094-1100). Oxford, UK: Elsevier Science Ltd.

Mullainathan, S. (2007). Psychology and Development Economics. In P. Diamond \& H. Vartiainen (Eds.), Behavioral Economics and Its Applications (pp. 85113). Princeton, NJ: Princeton University Press.

Ostaszewski, J. (2010). Finanse (Finance). Warszawa, Difin.

Plott, C. R., \& Smith, V. L. (Eds.). (2008). Handbook of experimental economics results (Vol. 1). Amsterdam: North Holland. 
Rabin, M. (1993). Incorporating fairness into game theory and economics. The American economic review, 83 (5), 1281-1302.

Rubinstein, A. (2006). Discussion of "Behavioral Economics". In R. Blundell, W. K. Newey, \& T. Persson (Ed.), Advances in Economics and Econometrics. Theory and Applications (Vol. 2, pp. 246-254). Cambridge, UK: Cambridge University Press.

Sanfey, A. G., Rilling, J. K., Aronson, J. A., Nystrom, L. E., \& Cohen, J. D. (2003). The neural basis of economic decision-making in the ultimatum game. Science, 300 (5626), 1755-1758.

Sanfey, A. G. (2007). Social decision-making: insights from game theory and neuroscience. Science, 318 (5850), 598-602.

Sedláček, T. (2012). Ekonomia dobra i zła. W poszukiwaniu istoty ekonomii od Gilgamesza do Wall Street [Economics of Good and Evil: The Quest for Economic Meaning from Gilgamesh to Wall Street]. Warszawa: Studio Emka.

Sepkowski, A. (2005). Człowiek a przyszłość [The human and the future]. Toruń: Wydawnictwo Adam Marszałek.

Schwartz, H. (2008). Guide to behavioral economics. Falls Church, VA: Higher Education Publications. Simon, H. A. (1955). A behavioral model of rational choice. Quarterly Journal of Economics, 69 (1), 99-118.

Simon, H. A. (1957). Models of man: social and rational: Mathematical essays on rational human behavior in a social setting. New York, NY: John Wiley \& Sons.

Smith, V. L. (2005). Behavioral economics research and the foundations of economics. Journal of Socio-Economics, 34 (2), 135-150.

Sontheimer, K. (2006). Behavioural versus neoclassical economics. Paradigm Shift Generalization? In M. Altman (Ed.), Handbook of contemporary Behavioral Economics: foundations and developments (pp. 237-256). New York, NY: Sharpe.

Stigler, G. (1965). The Development of Utility Theory. In Essays in the History of Economics. Chicago, IL: University of Chicago Press.

Szyszka, A. (2013). Behavioral Finance and Capital Markets: How Psychology Influences Investors and Corporations. New York, NY: Palgrave Macmillan.

Thaler, R. H. (2000). From homo economicus to homo sapiens. The Journal of Economic Perspectives, 14 (1), 133-141.
Thaler, R. H. (Ed.). (2005). Advances in behavioral finance (Vol. 2). Princeton, NJ: Princeton University Press.

Thaler, R. H., \& Sunstein, C. R. (2008). Nudge: Improving decisions about health, wealth, and happiness. New Haven, CT: Yale University Press.

Tversky, A., \& Kahneman, D. (1981). The framing of decisions and the psychology of choice. Science, 211 (4481), 453-458.

Tyszka T. (Ed.). (2004). Psychologia ekonomiczna [Economic psychology]. Gdańsk: Gdańskie Wydawnictwo Psychologiczne.

Watson, J. B. (1913). Psychology as the Behaviorist Views it. Psychological review, 20 (2), 158-177.

Wilkinson, N. (2008). An Introduction to Behavioral Economics. New York, NY: Palgrave Macmillan.

Witt, U. (2008). Evolutionary economics and psychology. In A. Lewis (Ed.), The Cambridge Handbook of Psychology and Economic Behaviour (pp. 493-511). Cambridge, UK: Cambridge University Press.

Wojtyna, A. (2008). Współczesna ekonomia - kontynuacja czy poszukiwanie nowego paradygmatu [Contemporary Economic Theory - Continuation or the Search for a New Paradigm?]. Ekonomista, 1, 9-32.

Zaleśkiewicz, T. (2011). Psychologia ekonomiczna [Economic Psychology]. Warszawa: PWN.

Zawiślak, A. M. (2011). O kwantach, rynkach i ekonomistach. Ikebana zadziwień i paradoksów [About quantums, markets and economists. An arrangement of surprises and paradoxes]. Warszawa: Poltext.

\section{Endnotes}

1 The hypothesis of the paper was formulated based on the Polish translation of Leibenstein's book. It is described in the references section at the end of the paper, with the page of the cited material also referring to the Polish edition. Leibenstein emphasized that homo oeconomicus is a specific case of the SR (selective rationality) human theory he had proposed. The Polish version, translated into English, reads as follows: "Although the theory presented here does not entirely eliminate the homo oeconomicus hypothesis, it is in general entirely different. Homo oeconomicus occurs in it as a specific case" (Leibenstein 1976, p. 427).

2 The author defines "stubborn facts" as facts that contradict the key assumptions of a paradigm, in this case, the neoclassical paradigm (Etzioni, 2011b, p. 1108). 